\title{
Studi Layout Furnitur dan Desain Pencahayaan di Lobby Apartemen Studi Kasus : Apartemen di Daerah Surabaya Timur
}

\author{
SB Astuti ${ }^{1}$, AW Anggraita ${ }^{2}$, SAHaq $^{3}$, SE Sitompul ${ }^{4}$, RDNGSaputra $^{5}$ \\ 1,2,3,4,5 Jurusan Desain Interior, Institut Teknologi Sepuluh Nopember, Surabaya, Indonesia \\ susy@interior.its.ac.id ${ }^{1)}$, ariaweny@interior.its.ac.id ${ }^{2)}$, \\ sagariarinal@gmail.com ${ }^{3)}$, fanienrica@gmail.com ${ }^{4)}$,redysaputra94@gmail.com ${ }^{5)}$
}

\begin{abstract}
ABSTRAK
Hubungan timbal balik antara suasana ruang (atmosphere) dengan perilaku sangat dipengaruhi oleh faktor kualitas desain interior ruang dan karakteristik dominan dari manusia yang berinteraksi di dalamnya. Dalam hal ini pengguna bersegmentasi pada golongan pelajar karena lingkungan berada di sekitar area pendidikan. Fokus penelitian adalah analisa kualitas desain pencahayaan dan layout furnitur di lobby apartemen.

Penelitian ini bertujuan mengetahui pengaruh kualitas interior ruang lobby terhadap interaksi pengguna apartemen di Surabaya Timur. Metode yang digunakan dalam penelitian kualitatif dengan pendekatan teknik observasi dan wawancara. Adapun teknik wawancara mendalam digunakan sebagai metode pendukung dengan tujuan untuk memperoleh kedalaman dan kelengkapan informasi dari penelitian. Observasi yang dilakukan terkait hubungan variabel yang akan diamati yakni layout furnitur dan perilaku terhadap interaksi antar pengguna apartemen, sedangkan wawancara mencari informasi kepada pengguna apartemen mengenai tingkat kenyamanan di lobby terhadap layout furnitur dan pencahayaan.

Hasil penelitian menunjukan bahwakenyamanan di ruang lobby apartemen diSurabaya timur sudah cukup dipertimbangkan, walaupun aspek layout furnitur serta pencahayaan masih bisa ditingkatkan lagi. Hal tersebut karena konsep layout furnitur dan desain pencahayaan masih menimbulkan glare serta backlight, sehingga mempengaruhi interaksi pengguna di lobby apartemen.
\end{abstract}

Kata Kunci : Layout furnitur, pencahayaan, lobby apartemen

\section{ABSTRACT}

Relationship lead reverse between atmosphere room and occupants behavior very be affected by the quality interior design and characteristics dominant of occupants that interacting. The student selected as respondents because the case of apartements environment located around the area of education. Focus of research about lighting and furniture layout in lobby apartments

This study aims to determine the effect on the quality of the interior lobby in the residents of apartments in East Surabaya. The method is qualitative research, with observation and interview technical. The in-depth interviews are used as a backup method for the purpose of obtaining a depth and completeness of the information from the study. Observations were made regarding the relationship variables that will be observed the furniture layout and behavior of the interaction between the apartment while the interviews are looking for information to users regarding the level of comfort in the apartment lobby of the layout of furniture and lighting.

The result of this researchis the aspect of comfort in lobby apartments at east Surabayahas been considered but in the other hand the layout of the furniture and the lighting is less convenient, the layout concept is less and the lighting is still causing glare and backlight, it affects user interaction at apartment lobby.

Keywords: Layout of furniture, lighting, lobby apartment 


\section{PENDAHULUAN}

Menurut Neufert (1980), apartemen adalah bangunan hunian yang dipisahkan secara horizontal dan vertikal, agar tersedia hunian yang berdiri sendiri dan mencakup bangunan bertingkat rendah atau bertingkat tinggi, dilengkapi dengan fasilitas-fasilitas yang sesuai dengan standart yang telah ditentukan. Tetapi ciri-ciri umum bangunan apartemen, sebagai berikut : Memiliki jumlah lantai lebih dari satu; terdiri atas beberapa unit hunian dalam satu lantai; setiap unit hunian terdiri atas minimal tiga macam ruang yaitu ruang tidur, dapur dan kamar mandi; setiap penghuni akan saling berbagi fasilitas yang ada pada apartemen; sirkulasi vertikal berupa tangga atau lift, sedangkan sirkulasi horizontalnya berupa koridor.

Berdasarkan penghuni, Paul Samuel (1967) membagi empat kelompok. Yaitu apartemen keluarga, apartemen lajang, apartemen pebisnis, apartemen manula. Apartemen keluarga adalah apartemen yang dihuni oleh keluarga yang terdiri dari ayah, ibu, dan anaknya. Sedangkan apartemen lajang dihuni oleh pria atau wanita yang belum menikah dan biasanya tinggal bersama temean mereka. Apartemen pebisnis/ekspatrial digunakan oleh para pengusaha untuk bekerja karena mereka telah mempunyai hunian sendiri di luar apartemen ini. Sementara apartemen manula merupakan apartemen yang menyesuaikan kondisi fisik penggunanya, yaitu para manula, dan mengakomodasi manula dengan alat bantu jalan. Apartemen di daerah Surabaya timur merupakan jenis apartemen lajang jika ditinjau melalui keadaan yang ada. Pengguna merupakan mahasiswa karena letak apartemen yang berada di area kampus.

Rancangan suatu bangunan/ lingkungan yang bagus akan menyebabkan orang merasa lebih nyaman, aman, dan produktif dan sebaliknya rancangan yang kurang baik akan membuat perasaan tidak berdaya (powerless) dan menimbulkan stres. Demikian juga dengan suatu rancangan lobby. Suatu rancangan lobby yang baik akan menyebabkan pengunjung merasa nyaman, aman, dan produktif. Konsekuesinya adalah apa yang akan dilakukan pengguna lobbyyang datang dengan maksud utama adalah menunggu atau bertemu orang lain, dapat berjalan dengan lancar dan semestinya. Lobby yang baik dalam perancanaan gedung apartemen perlu memperhatikan fungsi tiap ruang, unsur-unsur keharmonisan dan keindahan, baik dari segi interior maupun eksterior [3], oleh karenanya penelitian ini kajian lobby berdasarkan layout furnitur terhadap pencahayaan yang mempengaruhi interaksi kenyamanan pengguna lobby di apartemen khusunya apartemen di Surabaya Timur.

\section{METODOLOGI}

Metode yang digunakan dalam penelitian ini kualitatif yaitumelalui teknik wawancara dan observasi. wawancara mendalam digunakan untuk memperoleh kedalaman dan kelengkapan informasi dari penelitian. Observasi merupakan pengamatan langsung terhadap objek yang terkait dengan permasalahan. Pada kasus ini, pengamatan dilakukan terhadap objek yang menjadi batasan masalah yaitu lobby apartemen.

\section{DESKRIPSI}

\section{A. Pencahayaan Dalam Desain Interior}

Menurut Satwiko (2004) cahaya alami merupakan cahaya yang didapatkan dari sinar matahari secara langsung dari awal matahari terbit hingga terbenam. Pencahayaan adalah proses lengkap dalam mendesain bangunan untuk memanfaatkan cahaya alami secara 
maksimal. Desain Pencahayaan meliputi beberapa aspek yaitu mengorientasikan bangunan untuk memperoleh cahaya matahari secara optimal, pembentukan massa bangunan, menampilkan permukaan bangunan yang secara optimum menghadap ke arah matahari, memilih bukaan bangunan yang memungkinkan jumlah cahaya yang cukup masuk ke dalam bangunan, dengan memperhitungkan siklus matahari, musim, dan cuaca, menambahkan peralatan pelindung yang tepat dan dapat diatur, seperti kerai atau tirai, untuk memungkinkan penghuni bangunan untuk mengontrol cahaya matahari yang masuk ke dalam bangunan[1] .

Cahaya yang masuk ke dalam ruangan ada dua macam, yaitu cahaya alami dan cahaya buatan. Cahaya alami adalah cahaya yang ditimbulkan oleh matahari atau kubah langit. Cahaya matahari yang mengandung radiasi panas itu apabila masuk ke dalam ruangan akan menyebabkan kenaikan suhu ruangan. Cahaya buatan adalah cahaya yang dihasilkan dari usaha manusia seperti lampu pijar [2].

\section{B. Tata ruang Dalam Desain Interior}

Menurut Suptandar (1995), desain interior berarti suatu sistem atau cara pengaturan ruang dalam yang mampu memenuhi persyaratan kenyamanan, keamanan, kepuasan kebutuhan fisik dan spiritual bagi penggunanya tanpa mengabaikan faktor estetika. Terry (1966) berpendapat bahwa layout dipandang sebagai proses penentuan kebutuhan akan ruang dan tentang penggunaan ruangan secara terperinci guna menyiapkan susunan yang praktis dari faktor faktor fisik yang dianggap perlu untuk pelaksanaan kerja perkantoran dengan biaya yang layak. Keserasian dalam penataan ruang akan mempengaruhi produktivitas, efisiensi, efektifitas dan kenyamanan pemakai [2].

\section{PEMBAHASAN}

\section{A. Analisa Pola Interaksi Sosial}

Secara spasial, lobby apartemen merupakan ruang untuk publik yang diharapkan mampu memberikan besaran yang maksimal dapat dicapai oleh tatanan arsitekturalnya. Variabel keleluasaan pribadi / privacy dalam arti batasan spasial menjadi tidak relevan dalam ruang publik seperti lobby dan personal space tidak memiliki tingkatan atau hirarki sebagaimana di ruang-ruang dalam bagian apartemen yang lain.

Interaksi sosial dalam konteks suasana ruang ternyata juga dipengaruhi oleh tingkatan pengguna apartemen secara keseluruhan karena karakteristik umum dari pengunjung lobby ini adalah datang dari suatu kelompok atau dominannya adalah mahasiswa. Namun tetap ada pengguna lain yaitu yang sudah berkeluarga, pebisnis, maupun kaum manula, tapi tetap dominan penggunanya adalah kaum mahasiswa. Karena itulah maka seluruh pengunjung lobby, kecuali yang merupakan pengunjung tamu, seolah saling kenal secara hirarkis, walaupun sifatnya dari level bawah ke atas. Saling kenal seperti ini mengakibatkan sebagian pengguna seperti merasakan bahwa adanya 'jarak' akibat perbedaan 'level', walaupun di dalam ruang publik seperti pada lobby. Oleh karena itu pengguna lobby terkesan duduk berjauh-jauhan.

\section{B. Analisa Rancangan Pencahayaan Alami dan Respon Pengguna}

Pencahayaan alami adalah sumber pencahayaan yang berasal dari sinar matahari. Sumber 
pencahayaan alami kadang dirasa kurang efektif dibanding dengan penggunaan pencahayaan buatan, selain karena intensitas cahaya yang tidak tetap, sumber alami menghasilkan panas terutama pada siang hari.Kualitas rancangan pencahayaan alami diamati melalui pengamatan langsung di lapangan untuk mengetahui respon pengguna terhadap ruang lobby. Pengambilan data di lapangan ini dilakukan pada antara pukul 13.00 - 15.00. Dari hasil pengamatan lapangan didapatkan rancangan pencahayaan alami berada pada ambang cukup. Pada kondisi rancangan pencahayaan alami cukup, tingkat iluminasi memenuhi standar namun masih terdapat sinar matahari langsung masuk ke dalam ruangan. Hal ini disebabkan jendela pada ruang lobby memiliki kaca yang sangat besar serta berdekatan dengan area parkir sehingga cahaya matahari yang jatuh di area parkir mobil memantul ke dalam ruang lobby mengakibatkan kesilauan di dalam lobby meskipun sudah dilengkapi dengan elemen pembayangan (shading device).

Pencahayaan mengandung aspek kuantitas (intensitas cahaya) dan kualitas (warna kesilauan). Kesilauan dapat terjadi secara langsung (tersorot lampu) maupun tidak langsung (pantulan). Manusia menyukai lingkungan yang terang. Pada kumpulan manusia, mereka akan menyukai penerangan yang relatif merata, dan menghindari area yang terlalu terang. Menurut observasi yang penulis lakukan, umumnya pengguna lebih suka berada di tempat redup dan memandang ke tempat yang terang, daripada sebaliknya.

\section{Analisa Rancangan Pencahayaan Buatan dan Respon Pengguna}

Pada pencahayaan buatan, terdapat elemen-elemen perancangan, yaitu aspek fungsional dan aspek estetika. Aspek fungsional adalah peran pencahayaan sebagai penerang ruangan, sedangkan aspek estetika pada pencahayaan buatan akan menghasilkan kesan yang dirasakan oleh pengguna setelah ia melakukan aktivitas dalam sebuah ruangan dengan pencahayaan buatan di dalamnya. Selain sebagai penerang ruangan, cahaya dapat mempengaruhi suasana hati (mood) pengguna dan menciptakan suasana tertentu yang diinginkan untuk direpresentasikan dalam sebuah ruangan. Namun pada lobby apartemen ini, pencahayaan dinilai kurang menciptakan suasana dalam lobby. Pencahayaan buatan yang ada terkesan hanya untuk menerangi interior ruangan.

Pencahayaan buatan pada lobby juga tidak terlalu berefek pada suasana ruang. Pencahayaan buatan yang digunakan juga kurang variatif.Lampu yang digunakan hanya pencahayaan umum (general lighting) saja. Lobby sebuah apartemen harusnya menjadi tempat yang mengundang perhatian tamu dan juga fungsional. Kunci untuk mendapatkan suasana atmosfer yang nyaman di lobby apartemen adalah adanya interaksi antara lampu dekoratif dan lampu fungsional. Dimulai dari awal tamu masuk ke dalam apartemen, pencahayaan harus dapat membuat tamu merasa diterima dan juga harus dapat memikat pengunjung ke daerah-daerah tertentu di lobby yang membuat tamu dengan mudah mencapai tujuannya.

\section{Analisa Pengaruh Layout Ruang terhadap Pengguna Lobby Apartemen}

Desain interior mempunyai tujuan menciptakan suasana ruang agar menjadi lebih baik, lebih indah, dan lebih anggun sehingga dapat memuaskan dan menyenangkan bagi para pemakai ruang. Tujuan tersebut dapat tercapai dengan menerapkan beberapa cara antara lain :

1. Pemilihan dari material dan elemen ruang yang sesuai dengan fungsinya.

2. Pengaturan keserasian dalam penyusunan perabot.

3. Dimensi perabot yang proposional terhadap besaran ruang. 
4. Menciptakan suasana ruang yang sesuai dengan fungsi dan kehendak pemakai.

5. Pengaturan perabot sesuai dengan tujuan dan fungsinya dengan tidak mengabaikan sirkulasi pemakai ruang.

6. Pengaruh warna dan pola dekorasi ruang sangat penting dalam menciptakan kesan psikologis dan optis pada pemakai ruang tersebut.

Ruang yang terbagi atas beberapa susunan bentuk atau denah, dan hal ini harus selalu dikerjakan atas bentuk geometris supaya kelihatan jelas. Demikian juga pada lobby apartemendi Surabaya timur. Guna mencapai keharmonisan dalam lobby, dibutuhkan batas kejelasan yang tepat dan kesan terlindung.Kalau pembagian ruang dibuat dengan menempatkan perabot atau sekat berjeruji, maka kesan luas dan terbuka masih dapat dipertahankan. Kesan ruang tersebut akan terlihat megah penuh dinamik, sesuai dengan selera zaman sekarang.

Tata ruang disusun berdasarkan tujuan dan fungsinya untuk mendapatkan komposisi ruang yang baik, diperlukan kesatuan bagian-bagian dalam ruang. Kesatuan tersebut dapat diperoleh dengan pengaturan yang baik dan pandangan yang serasi. Kegunaan suatu susunan harus merupakan harmoni dengan tuntutan tata ruang yang serasi dan indah.Susunan suatu ruang harus sesuai dengan tujuannya, maksudnya ialah penggunaan dan penyusunan perabot ditentukan oleh kebutuhan praktis dan kebiasaan hidup dari penggunanya. Perabot yang digunakan untuk mencapai tujuan yang sama disatukan menjadi satu kelompok fungsi. Kesatuan-kesatuan fungsi itu tetap harus diatur baik, sehingga masih tersedia ruang sirkulasi. Maka harus perhatikan bahwa pengelompokan perabot menurut fungsinya merupakan dasar penyusunan ruang dengan sirkulasi yang baik. Pada lobby ini penyusunan perabot sudah baik bagi pengunjung, perabot kursi dan meja tamu yang mempunyai fungsi sama dijadikan dalam satu kumpulan sehingga tidak mengganggu sirkulasi ruang yang terbentuk.

Jadi dalam perancangan suatu interiorlobby apartemen perlu dimunculkan kesan yang sesuai dengan karakteristik dari apartemenpada umumnya. Karakteristik yang muncul harusnya berupa suatu kesan keruangan yang alami, penuh dengan unsur ketenangan, santai dan nyaman. Kesan yang muncul inilah yang mempunyai pengaruh pada pengunjung yang membutuhkan suatu ruang yang tenang dan santai. Kesan ruang ini dapat muncul melalui pembentukan dan pengolahan interior ruang, serta pewarnaan ruang yang memenuhi syarat perancangan suatu lobby apartemen.

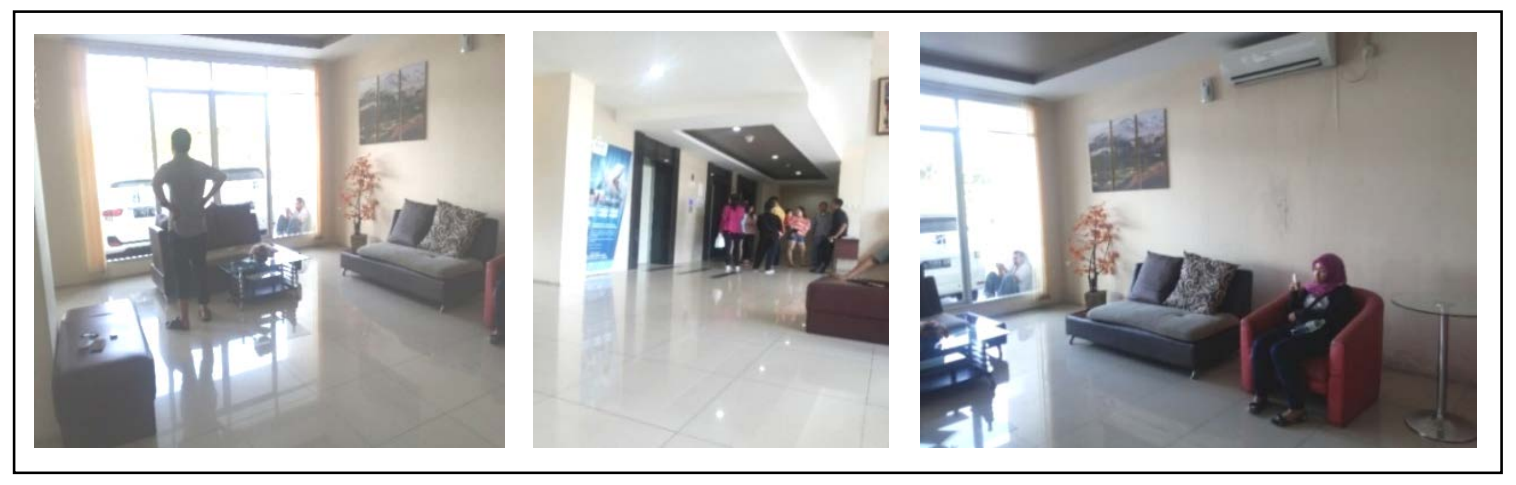

Gambar 1. Lobby Apartemen Obyek 1

Sumber : Dokumentasi Penulis (2015) 


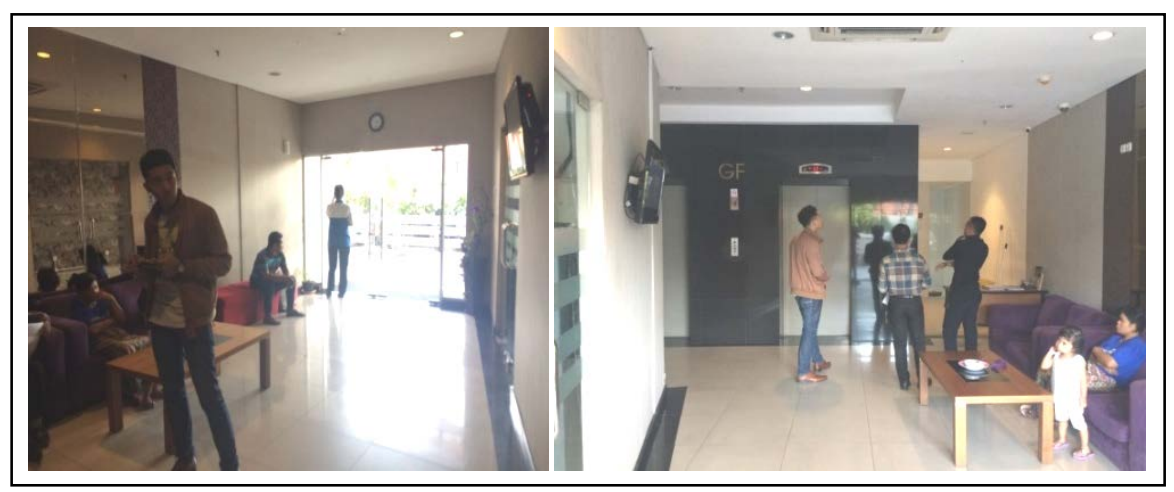

Gambar 2. Lobby Apartemen Obyek 2

Sumber : Dokumentasi Penulis (2015)

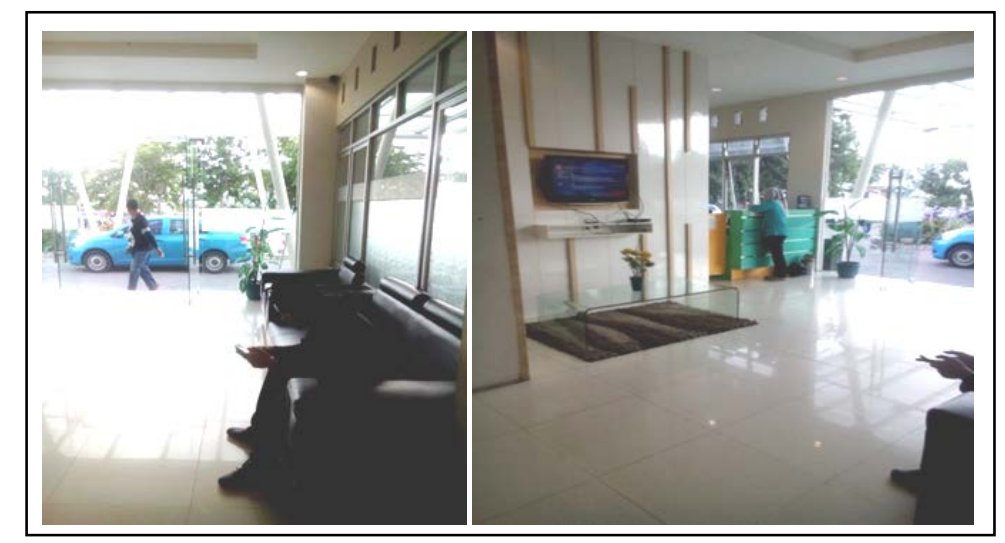

Gambar 3. Lobby Apartemen Obyek 3

Sumber : Dokumentasi Penulis (2015)

Dari hasil observasi seperti gambar 1, 2 dan 3, layout furnitur lobby apartemen sudah baik karena tidak terlalu sempit dan luas serta penataan layout furnitur tidak mengganggu sirkulasi dalam lobby tetapi pemilihan warna dan konsep warna furnitur kurang baik.

Pada gambar 1, 2 dan 3 di atas juga dapat terlihat jendela di lobby apartemen memiliki kaca yang besar sehingga cahaya langusung masuk ke dalam ruangan, jika menghadap keluar jendela akan backlight.

\section{E. Analisa Korelasional Rancangan Pencahayaan serta Layout Furnitur Lobby Apartemen di Surabaya timur dan Respon Pengguna.}

Analisa korelasional menjelaskan hubungan antara persepsi pengguna ruangan terhadap kondisi pencahayaaan dan layout furnitur ruangannya. Wawancara dilakukan terhadap 6 responden di setiap apartemen. Hasil wawancara pada setiap pengguna apartemen dirangkum dalam bentuk tabel grafik yang disesuaikan dengan pertanyaan yang telah diajukan saat wawancara. Ada 5 hal yang akan dibahas, yaitu:

1. Intensitas Pengguna Lobby Apartemen di Surabaya Timur.

Lobby merupakan area yang sangat penting dalam bangunan apartemen, setiap orang yang datang ke apartemen, pengguna maupun pengunjung apartemen, pasti melewati lobby terlebih dahulu. Oleh karena itu pasti tidak ada yang tidak pernah menggunakan lobby. Fasilitas yang ada di lobby adalah area duduk dan pusat informasi. 


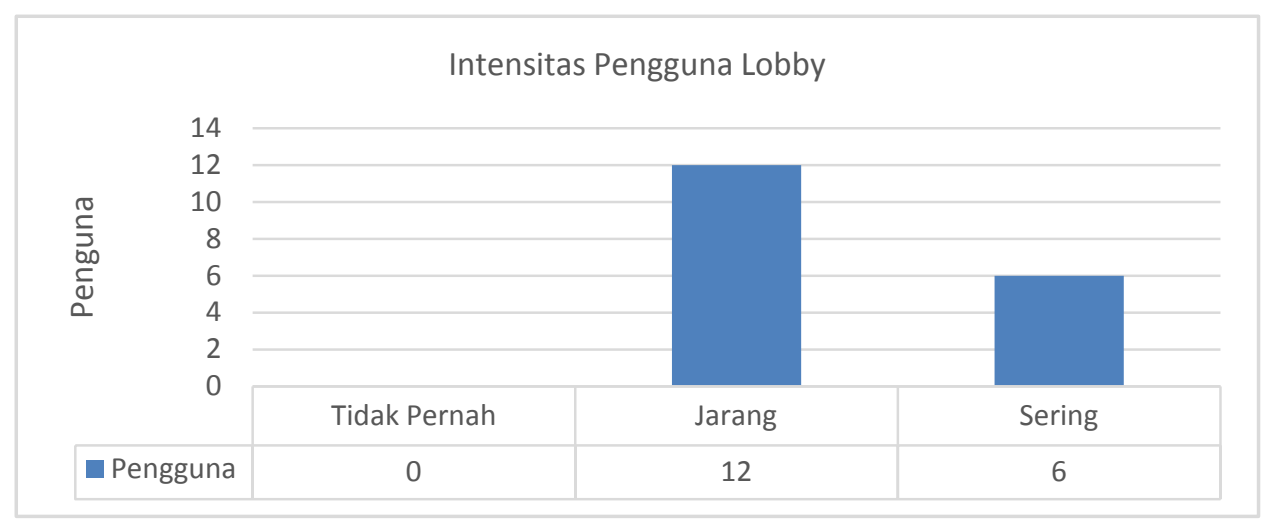

Gambar 4. Intensitas Pengguna Lobby Apartemen di Surabaya timur

Gambar 4 di atas menunjukkan bahwa hasil wawancara terhadap 6 responden di setiap apartemen cenderung jarang berada di lobby karena mereka hanya menggunakan lobby ketika menunggu orang, menunggu lift, mencari informasi atau bahkan hanya sekedar lewat saja.

2. Aktivitas di Lobby Apartemen Daerah Surabaya Timur.

Pada umunya fasilitas di lobby apartemen bermacam - macam. Ada area duduk, area informasi, area bermain dan area santai/café, namun di lobby apartemen daerah Surabaya timur hanya tersedia area duduk, tidak ada area bermain atau area café bahkan di area informasi hanya terpasang 1 meja kecil yang tidak jelas signed serta terkadang tidak ada petugas yang menjaga sehingga berdasarkan hasil wawancara terhadap 6 pengguna di setiap apartemen di Surabaya timur mereka hanya melakukan aktivitas menunggu teman, menunggu lift dan duduk. Berdasarkan tabel 2 di bawah, maka aspek aktivitas dominan adalah menunggu teman dengan jumlah 9 orang dikarenakan fasilitas yang tersedia hanya area duduk dan aktivitas menunggu lift hanya 6 yang menjawab karena aktivitas menunggu lift dapat dilakukan dengan berdiri didepan liftnya langsung tanpa menggunakan fasilitas yang ada di lobby, sedangkan pengguna yang menjawab duduk hanya 3 orang karena aktivitas tersebut jarang dilakukan mengingat fasilitas di lobby yang terbatas dan kurang menarik menurut pengguna.

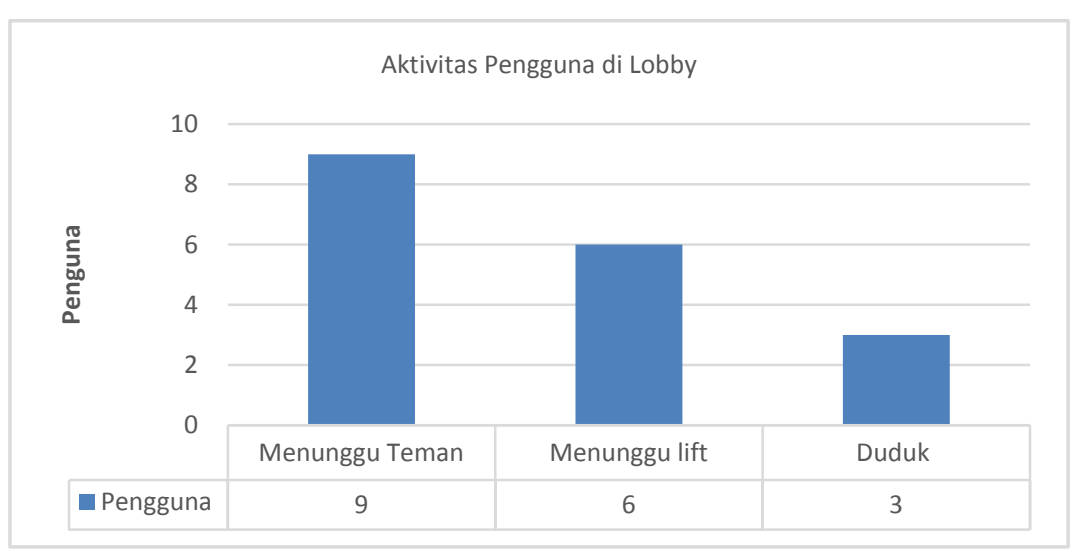

Gambar 5. Aktivitas Pengguna di Lobby Apartemen di Surabaya Timur 
3. Pencahayaan di Lobby Apartemen Daerah Surabaya Timur.

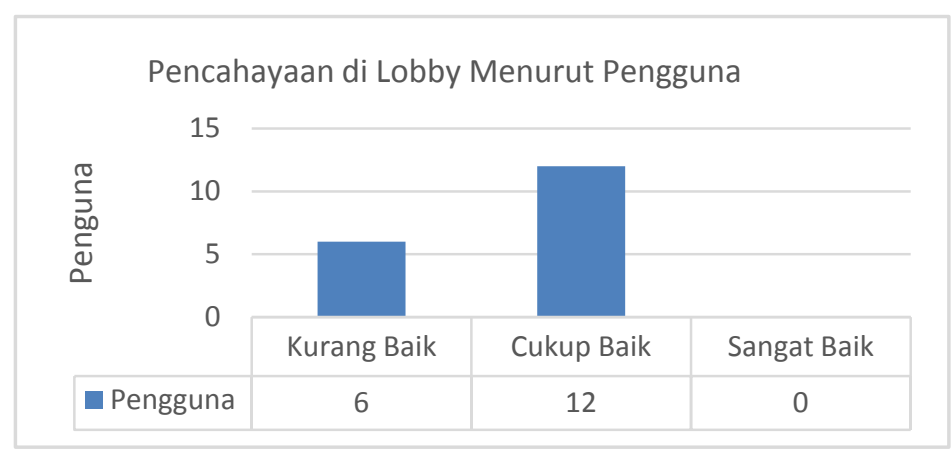

Gambar 6. Pencahayaan di Lobby Apartemen di Surabaya Timur

Faktor pencahayaan sangat penting dalam sebuah interior ruang. Lobby apartemen harus mempunyai pencahayaan yang baik karena merupakan first point seseorang ketika memasuki sebuah apartemen. Berdasarkan hasil wawancara sejumlah 6 orang menjawab pencahayaan di lobby kurang baik, 12 orang menjawab sudah cukup baik dan tidak ada yang menjawab sangat baik. Pengguna apartemen yang menjawab kurang baik mengatakan jendela lobby apartemen di Surabaya timur terlalu besar sehingga cahaya yang memantul mengakibatkan kesilauan dan ada beberapa area lobby kurang terang karena lobby berada dibawah gedung sehingga ada area yang tidak terjangkau sinar matahari.

4. Layout Furnitur di Lobby Apartemen di Surabaya Timur.

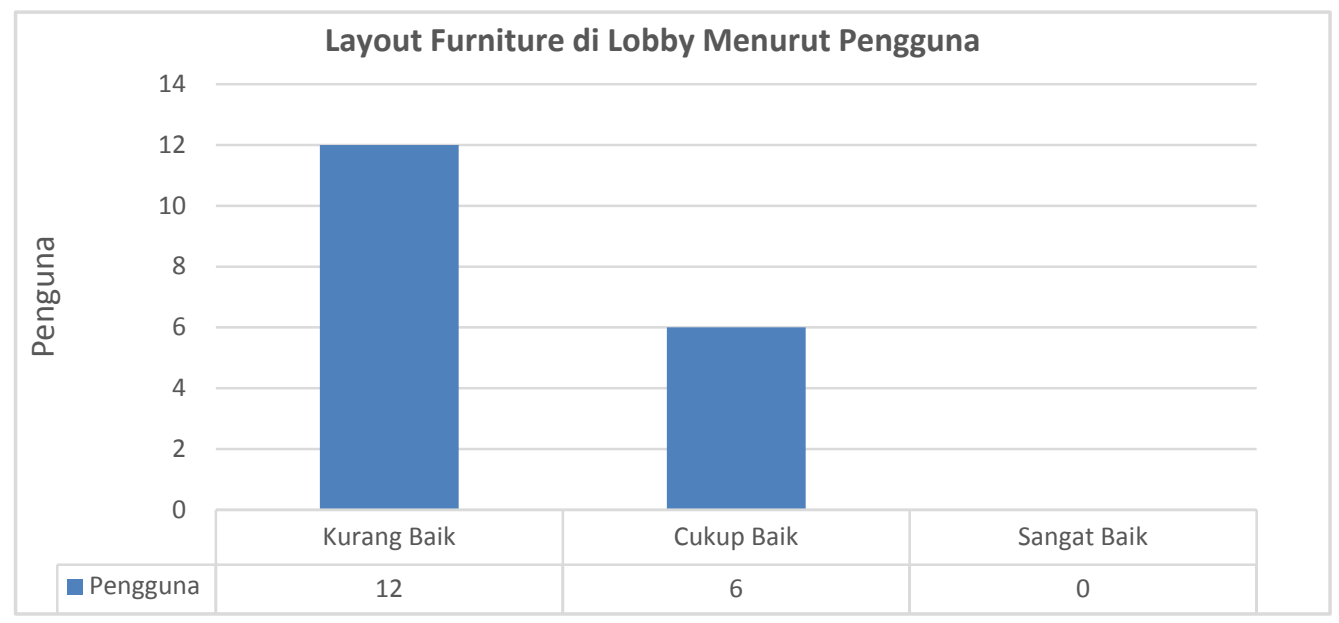

Gambar 7. Layout Furnitur di Lobby Apartemen di Surabaya Timur

Layout furnitur di lobby harus dirancang sebaik mungkin agar pengguna merasa nyaman ketika berada di lobby dan ketika melakukan aktivitas. Berdasarkan hasil wawancara terhadap 6 pengguna di setiap apartemen di Surabaya timur cenderung menjawab kurang baik. Tepatnya 12 orang menjawab kurang baik, 6 orang menjawab cukup baik dan tidak ada yang menjawab sangat baik. Menurut 12 pengguna yang menilai dengan kurang baik mengatakan pemilihan warna furnitur kurang bagus, warnanya biasa saja tidak menarik, menurut mereka furnitur di lobby seperti tidak difikirkan dengan baik - baik dengan pemasangan furnitur seadanya dan tidak terkonsep sehingga terkesan biasa saja tidak eksklusif sepeti pada umumnya lobby. Sedangkan 
menurut 6 pengguna yang lain, lobby apartemen di daerah Surabaya timur cukup baik karena sudah memenuhi standart lobby yang memiliki area duduk.

5. Kenyamanan Pengguna Lobby Apartemen di Surabaya Timur.

Pembahasan materi wawancara yang terakhir mengenai kenyamanan pengguna di lobby Apartemen di Surabaya timur. Kenyamanan adalah faktor utama yang diperlukan dalam merancang sebuah ruangan. Semakin baik suatu ruang bila tingkat kenyamanan tinggi. Berdasarkan hasil wawancara terhadap 6 pengguna lobby di setiap apartemen di Surabaya timur, 6 pengguna merasa kurang nyaman sedangkan 12 pengguna merasa cukup nyaman dan tidak ada yang merasa sangat nyaman. Pengguna lobby apartemen merasa kurang nyaman karena layout furnitur yang kurang jumlahnya serta kesilauan pencahayaan sedangkan 12 lainnya menjawab cukup nyaman karena fasilitas sudah ada standar lobby dan tetap bisa melakukan aktivitas seperti biasanya.

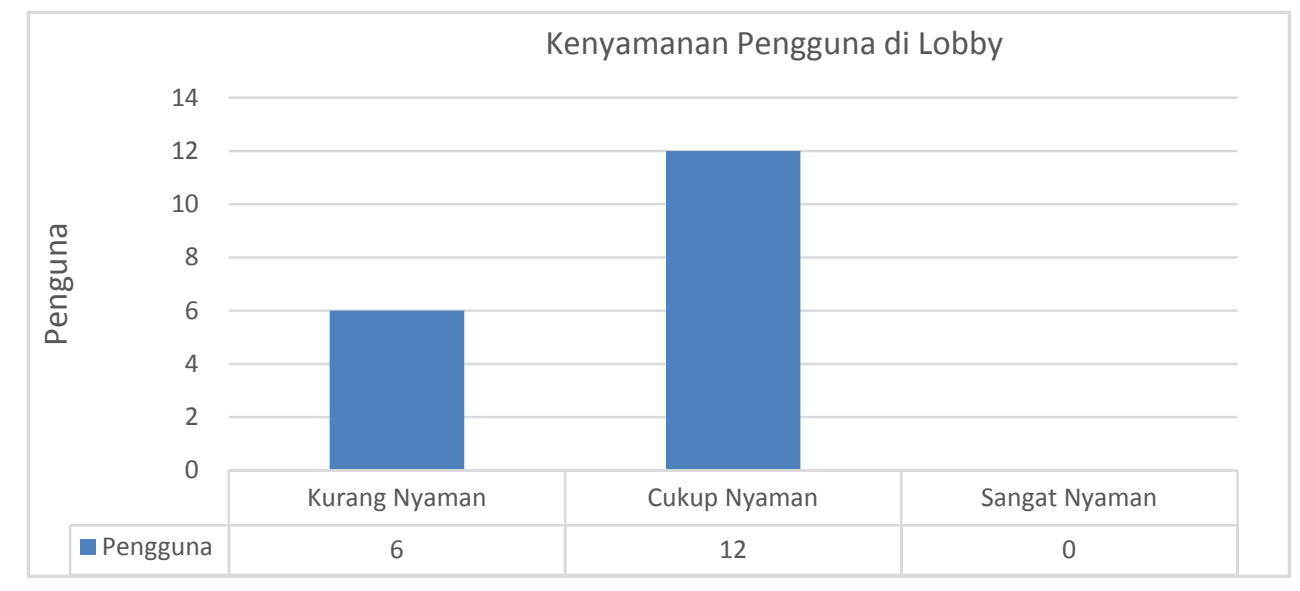

Gambar 8. Kenyamanan Pengguna di Lobby Apartemen di Surabaya Timur

Berdasarkan pembahasan hasil wawancara diatas dapat dilihat bahwa :

1. Pencahayaan lobby cukup baik karena ukuran jendela yang besar, sehingga ruangan dapat tersinari dengan baik. Namun dengan ukuran yang besar itu juga menimbulkan kerugian, karena terkadang hamparan cahaya matahari yang jatuh ke kaca mobil memantulkan kedalam ruang lobby menyebabkan silau kepada pengguna lobby sehingga mengganggu aktivitas yang ada.

2. Konsep layout furnitur di lobby apartemendi Surabaya timur masihkurang menarik penataannya.

3. Respon pengguna terhadap ruang lobby beragam dari positif hingga negatif, mayoritas memberikan respon sedang (cukup sesuai dengan kenyamanan pengguna). Beberapa respon kontradiktif terhadap hasil pengamatan dan pengukuran, namun dapat dipahami karena pengguna telah mengadaptasi dan memodifikasi kondisi ruangnya (melalui tata perabot) sehingga tetap dapat merasa nyaman.

\section{KESIMPULAN}

Kesimpulan yang dapat diambil dari pembahasan diatas sebagai berikut :

1. Parameter kenyamanan lobby hunian apartemen dapat ditinjau antara lain dari desain pencahayaan, desain layout furnitur serta fungsi dari lobby itu sendiri. Aspek tersebut 
tidak selalu mampu hadir optimal semua, karena masing masing aspek ada variabel yang tidak sama.

2. Pada ruang lobby apartemen di daerah Surabaya timur dari segi kenyamanan sudah dianggap baik namun dari segi layout furnitur serta pencahayaan kurang nyaman, ini di lihat dari kurang terkonsepnya layout serta pencahayaan yang masih menimbulkan efek silau serta backlight.

\section{PUSTAKA}

[1] Karlen. (2007).Design, Synthesis, and Characterization of Amphidynamic Materials.

[2] Lasa. (2005),Manajemen Perpustakaan. Yogyakarta : Gama Media

[3] Marlina, Endy. (2008). Panduan Perancangan Bangunan Komersial, Jakarta : Erlangga

[4] Neufert, Ernst. (2002). Data Arsitek Edisi 33 Jilid 1, Jakarta : Erlangga

[5] Paul, Samuel. (1967). Apartment: The Design and Development, New York :Reinhold Pub.Co.

[6] Satwiko, P. (2004),Fisika Bangunan 1, Yogyakarta : Andi

[7] Suptandar, Pamudji. (2005),Ilmu Komunikasi: suatu pengantar.Jakarta : Universitas Trisakti

[8] Terr. (1996). Environmental Design and Human Behavior: A Psychology of the Individual in Society. 